\title{
Risk factors for postoperative ileus following loop ileostomy closure
}

\author{
Aydın Aktaş ${ }^{1}$ (D), Cüneyt Kayaalp ${ }^{2}$ (D), Mustafa Ateş ${ }^{3}$ (D) Abuzer Dirican $^{3}$ (D) \\ ${ }^{1}$ Department of General Surgery, Karadeniz Technical University, School of Medicine, Trabzon, Turkey \\ 2 Department of Gastointestinal Surgery, Inönü University, School of Medicine, Malatya, Turkey \\ ${ }^{3}$ Department of General Surgery, Inönü University, School of Medicine, Malatya, Turkey
}

\begin{abstract}
Objective: The most common intra-abdominal complication following loop ileostomy closure (LIC) is postoperative ileus (POI). The aim of the study was to determine the risk factors of POI development following LIC and make recommendations for its prevention.

Material and Methods: In this study, patients having undergone LIC with peristomal incision following distal colorectal surgery were included. Clavien-Dindo classification was used to evaluate postoperative complications. POI and postoperative leakage were defined based on clinical and radiological criteria. The Centers for Disease Control and Prevention 2017 criteria were used to diagnose surgical site infection (SSI). Postoperative bleeding was diagnosed one day after surgery if there was a $>2 \mathrm{~g} / \mathrm{dL}$ or $\geq 15 \%$ decrease in the hemoglobin level.

Results: Seventy-nine patients were included into the study. In nine of the patients POI developed, six had SSI, five had postoperative bleeding, and two had anastomosis leakage. In the univariate analysis; age $<60$ years $(p=0.02)$, presence of comorbidity $(p=0.007)$, using an open technique in the first surgery ( $p=0.02)$, performing total colectomy in the first surgery $(p=0.048)$, performing hand-sewn anastomosis of LIC ( $p=0.01)$, and postoperative blood transfusion ( $p=0.04$ ) were found to be risk factors for POI. Performing hand-sewn anastomosis of LIC $(p=0.03)$ and using an open technique in the first surgery $(p=0.03$ ) were found to be independent variables for POI risk.
\end{abstract}

Conclusion: Using an open technique in the first surgery and performing a hand-sewn anastomosis of LIC may increase POI.

Keywords: lleostomy reversal, small bowel obstruction, colorectal surgery, hand-sewn anastomosis, laparoscopy

Cite this article as: Aktaş A, Kayaalp C, Ateş M, Dirican A. Risk factors for postoperative ileus following loop ileostomy closure. Turk J Surg 2020; 36 (4): 333-339.

Corresponding Author

Aydın Aktaş

E-mail: aydinaktas2004@gmail.com

Received: 29.09 .2020

Accepted: 03.10.2020

Available Online Date: 29.12.2020

( C) Copyright 2020 by Turkish Surgical Society Available online at www.turkjsurg.com

DOI: 10.47717/turkjsurg.2020.4911

\section{INTRODUCTION}

Loop ileostomy closure (LIC) is associated with postoperative morbidity, reoperation, and mortality at rates of up to $45 \%, 7 \%$, and $3.7 \%$, respectively (1-7). The most common complications are anastomosis leakage, gastrointestinal hemorrhage, surgical site infection (SSI), and postoperative ileus (POI). POI is the most common complication following LIC with a rate of $4.1 \%-32.6 \%$ (2-4). POI is the biggest obstacle for a successful enhanced recovery after surgery protocols $(8,9)$, and it is the most important cause of hospitalization within the first 30 days postoperatively (10). POI rises healthcare costs by increasing the risk of hospital-acquired infections $(5,6)$, and it usually improves with conservative treatment (11).

The incidence of POI following LIC and its risk factors vary in the literature. The aim of this study was to determine the risk factors of POI development following LIC and make recommendations for its prevention.

\section{MATERIAL and METHODS}

This retrospective study was approved by the Ethics Committee of Inonu University (decision no: 2017/26-2). We scanned the medical records of adult patients who had undergone elective ileostomy closure after distal colorectal surgery in Inonu University General Surgery Clinic between January 2009 and September 2018. Patients who had undergone LIC with peristomal incision following distal rectal/anal anastomosis were included into this study. Patients undergoing additional surgery 
during LIC and simultaneous ileostomy-colostomy at other localizations and those whose incisions were left to recover by secondary wound healing or whose wounds were closed with Bogota bag were excluded from the study.

\section{Surgical Technique}

All procedures were performed under general anesthesia. Surgical site was cleaned with povidone iodine antiseptic solution (Kansuk laboratory, Turkey), and the patients were covered with sterile surgical drapes; 1 gr IV cefazolin was administered 30 minutes before the surgery for antibiotic prophylaxis and was terminated at postoperative 24 hours. In case surgery duration exceeded four hours and intraoperative bleeding was $1500 \mathrm{ml}$, an additional $1 \mathrm{gr}$ of IV cefazolin was administered. A peristomal circular elliptical incision was used to mobilize the fascia and the peritoneal adhesions surrounding the mouth of the loop ileostomy. According to the surgeon's preference, side-to-side anastomosis was performed using a linear stapler (DST Series 80 mm-3.8 mm, Covidien, USA) while end-to-end anastomosis was hand-sewn with an absorbable 3/0 suture (Vicryl, Ethicon Inc., Cincinnati, OH, USA). Lambert sutures were placed with a non-absorbable 3/0 suture (Prolene, Ethicon, USA) according to the surgeon's preference. The intestine was then replaced into the abdominal cavity, and the abdominal fascia was closed with a non-absorbable 2/0 suture (Prolene, Ethicon, USA). Subcutaneous tissues were closed with absorbable 3/0 suture (PDS, Ethicon, USA), while the skin was closed using the primary or purse suture technique with a non-absorbable $3 / 0$ suture (Prolene, Ethicon, USA), according to the surgeon's preference. Penrose drain was placed under the skin according to the surgeon's preference and was removed on the first postoperative day. Liquid diet was started on the first postoperative day, and wound dressing was done with povidone iodine solution for the first 48 hours.

\section{Definitions}

Distal rectal or anal anastomosis was defined as anastomosis performed below the pelvic peritoneal reflection. Clavien-Dindo classification was used to evaluate postoperative complications (POC). POI was defined clinically (intolerance to oral intake, abdominal distension, nausea, vomiting, abdominal pain, inability to remove gas-stool, and fever) and radiologically (dilatation of small bowel loops and air-fluid level in abdominal X-ray or computed tomography) during the postoperative 30-day period. Postoperative leakage was diagnosed clinically (nausea, vomiting, abdominal pain, and fever) and radiologically (air-fluid level in the small intestines on abdominal X-ray, small intestine level on abdominal computed tomography, and presence of intra-abdominal purulent or fecaloid content). Postoperative bleeding was diagnosed one day after surgery if there was a $>2 \mathrm{~g} / \mathrm{dL}$ or $\geq 15 \%$ decrease in the hemoglobin level. The Centers for Disease Control and Prevention (CDC) 2017 criteria were used to diag- nose SSI12. SSI was classified according the CDC classification system as follows: (1) superficial incisional involving only the skin or subcutaneous tissue of the incision; (2) deep incisional involving the fascia and/or muscular layers in the primary incision (deep incisional primary) in a patient having undergone an operation involving one or more incisions and an SSI identified in the secondary incision (deep incisional secondary) in an operation with more than one incision; and (3) organ space involving any part of the body opened or manipulated during the procedure, excluding the skin incision, fascia, or muscle layers. In the presence of more than one SSI type, the more complex SSI type was selected.

Age, sex, comorbidity, American Society of Anesthesiologists score, first operation, pathology of the first specimen, neoadjuvant and adjuvant therapy, LIC duration, type of anastomosis, duration of the operation, amount of intraoperative bleeding, POC, length of hospital stay, and mortality were recorded.

\section{Statistical Analysis}

Data were analyzed using the SPSS 22 software. Shapiro-Wilk test was used for testing normality. Chi-square and Mann-Whitney $\mathrm{U}$ tests were used for categorical and continuous variables, respectively. Logistic regression analysis was performed for variables that had P-values $<0.05$ in the univariate analyses. P-values $<0.05$ were considered statistically significant.

\section{RESULTS}

lleostomy was closed in 142 patients who had colorectal surgery. A total of 79 patients having undergone LIC following distal rectal or ileoanal anastomosis were included. Patients who had undergone end-ileostomy closure $(n=29)$, non-colorectal LIC $(n=14)$, non-distal rectal and ileoanal anastomosis $L I C(n=8)$, and additional surgery during LIC $(n=12)$ were excluded. Median age was 55 (18-93) years, and $62.0 \%$ of the patients were males. Loop ileostomy was performed in $81.0 \%$ of the patients due to colorectal cancer, using the laparoscopic technique in $68.4 \%$ of them. The median interval between loop ileostomy creation and closure was 202 (14-576) days. A total of 16.5\% of the patients received neoadjuvant chemoradiotherapy, and $50.6 \%$ of them received adjuvant chemotherapy. Median operation duration of LIC was 54 (40-80) minutes. A total of $77.2 \%$ of LIC surgeries was performed with a stapler. Demographic characteristics of the patients included in the study are shown in Table 1.

Twenty-two intra-abdominal complications (Clavien-Dindo 2, $3 \mathrm{~A}, 3 \mathrm{~B})$ developed in 14 patients (17.7\%) within the first 30 days postoperatively. $\mathrm{POI}$ was observed in nine patients (11.4\%). POI was diagnosed clinically and radiologically in seven patients and all recovered with medical treatment. POI developed in two patients who experienced anastomosis leakage on the sixth and tenth postoperative days. One of these patients underwent primary repair and the other underwent loop ileostomy. Post- 


\begin{tabular}{|c|c|c|}
\hline Parameters & $n=79$ & $\%$ \\
\hline Age (years) (median, range) & $55(18-93)$ & \\
\hline \multicolumn{3}{|l|}{ Gender (n, \%) } \\
\hline Male & 49 & 62.0 \\
\hline Female & 30 & 38.0 \\
\hline Comorbidity (n, \%) & 31 & 37.8 \\
\hline Hypertension & 18 & 21.9 \\
\hline Diabetes Mellitus type 2 & 10 & 12.2 \\
\hline Chronic obstructive pulmonary disease & 5 & 6.1 \\
\hline Coronary artery disease & 4 & 4.8 \\
\hline Epilepsy & 1 & 1.2 \\
\hline \multicolumn{3}{|l|}{ Loop ileostomy etiology $(n, \%)$} \\
\hline Rectum Cancer & 58 & 73.4 \\
\hline Rectal villous adenoma & 6 & 7.6 \\
\hline FAP & 5 & 6.3 \\
\hline FAP + Rectum Cancer & 4 & 5.1 \\
\hline Ulcerative colitis & 3 & 3.8 \\
\hline Others & 3 & 3.8 \\
\hline \multicolumn{3}{|l|}{ First surgical technique for LIC (n, \%) } \\
\hline Open & 25 & 31.6 \\
\hline Laparoscopy & 54 & 68.4 \\
\hline Interval between ileostomy creation and closure (day) (median, range) & $202(14-576)$ & \\
\hline Operation duration (minute) (median, range) & $54(40-80)$ & \\
\hline \multicolumn{3}{|l|}{ Postoperative complications ( $n, \%)$} \\
\hline Ileus & 9 & 11.4 \\
\hline Gastrointestinal hemorrhage & 5 & 6.3 \\
\hline Surgical site infection & 6 & 7.6 \\
\hline Anastomosis leak & 2 & 2.5 \\
\hline Lenght of stay (day) (median, range) & $6(3-14)$ & \\
\hline
\end{tabular}

operative lower gastrointestinal bleeding was observed in five patients (hematochezia in two patients and melena in three patients). Only three of these patients gave blood transfusions (three, three, and four units of erythrocyte transfusion). Skin incision was closed with primary sutures in 75 patients and purse sutures in four patients. SSI developed in six patients whose incision had a primary closure (superficial SSI in two patients, deep SSI in one patient, and organ/space SSI in three patients). However, incision closure type was not associated with SSI (8.0\% vs. $0 \%, p=1.00)$. Length of hospital stay was six days longer in patients with POI. Six patients were re-hospitalized after discharge. Three of them had SSI, one had an anastomosis leak, one had $\mathrm{POI}$, and one had abdominal pain. No patient died within the first postoperative 30 days.

In the univariate analysis, age $<60$ years $(p=0.02)$, presence of comorbidity ( $p=0.007)$, using an open technique in the first surgery $(p=0.02)$, performing total colectomy in the first surgery $(p=0.048)$, performing hand-sewn anastomosis of LIC $(p=0.01)$, and postoperative blood transfusion $(p=0.04)$ were found to be risk factors for POI (Table 2). Performing hand-sewn anastomosis of LIC (OR: 6.250, $p=0.03$ ) and using an open technique in the first surgery (OR: 6.400, $p=0.03$ ) were found to be independent variables for $\mathrm{POI}$ risk (Table 3 ).

\section{DISCUSSION}

$\mathrm{POI}$ is defined as the transient inhibition of normal gastrointestinal motility after abdominal surgery. The function of the small intestine recovers within 24 hours, stomach function within 3648 hours, and colon function within 48-72 hours, postoperatively. Thus, in uncomplicated $\mathrm{POI}$, gastrointestinal motility recovers within three days. If the recovery of the gastrointestinal motility exceeds three days, it is considered to be complicated and paralytic ileus or mechanical bowel obstruction is considered to have occurred (13). POI is characterized clinically by abdominal pain and distension, nausea, and vomiting, as well as the inabil- 
Table 2. Risk factors for postoperative ileus

\begin{tabular}{|c|c|c|c|}
\hline Parameters & $\begin{array}{l}\text { POI } \\
n=9\end{array}$ & $\begin{array}{c}\text { No-POI } \\
n=70\end{array}$ & $\mathrm{p}$ \\
\hline $\begin{array}{l}\text { Age }(n, \%) \\
\geq 60 \\
<60\end{array}$ & $\begin{array}{c}0(0) \\
9(17.6)\end{array}$ & $\begin{array}{l}28(100.0) \\
42(82.4)\end{array}$ & 0.02 \\
\hline $\begin{array}{l}\text { Gender }(n, \%) \\
\text { Male } \\
\text { Female }\end{array}$ & $\begin{array}{l}6(12.2) \\
3(10.0)\end{array}$ & $\begin{array}{l}43(87.8) \\
27(90.0)\end{array}$ & 0.76 \\
\hline Comorbidity (n, \%) & $7(24.1)$ & $22(75.9)$ & 0.007 \\
\hline $\begin{array}{l}\text { ASA score }(n, \%) \\
\mid \\
\| \\
\| \mid\end{array}$ & $\begin{array}{c}0(0) \\
7(12.3) \\
2(13.3)\end{array}$ & $\begin{array}{l}7(100.0) \\
50(87.7) \\
13(86.7)\end{array}$ & 0.61 \\
\hline $\begin{array}{l}\text { First operation }(n, \%) \\
\text { Open } \\
\text { Laparoscopic }\end{array}$ & $\begin{array}{l}6(24.0) \\
3(5.6)\end{array}$ & $\begin{array}{l}19(76.0) \\
51(94.4)\end{array}$ & 0.02 \\
\hline $\begin{array}{l}\text { First operation type }(\mathrm{n}, \%) \\
\text { Total colectomy } \\
\text { Low anterior resection }\end{array}$ & $\begin{array}{c}3(30.0) \\
6(8.7)\end{array}$ & $\begin{array}{l}7(70.0) \\
63(91.3)\end{array}$ & 0.048 \\
\hline $\begin{array}{l}\text { First pathology }(n, \%) \\
\text { Benign } \\
\text { Malign }\end{array}$ & $\begin{array}{l}3(20.0) \\
6(9.4)\end{array}$ & $\begin{array}{l}12(80.0) \\
58(90.6)\end{array}$ & 0.30 \\
\hline Neoadjuvant chemoradiotherapy (n, \%) & $1(7.7)$ & $12(92.3)$ & 0.60 \\
\hline Adjuvant chemotherapy $(n, \%)$ & $3(7.5)$ & $37(92.5)$ & 0.22 \\
\hline $\begin{array}{l}\text { Interval between ileostomy creation and closure (month) (n, \%) } \\
\leq 2 \\
>2\end{array}$ & $\begin{array}{l}1(12.5) \\
8(11.3)\end{array}$ & $\begin{array}{l}7(87.5) \\
63(88.7)\end{array}$ & 1.00 \\
\hline Operation duration (minute) (median, range) & $45(40-50)$ & $55(45-80)$ & 0.36 \\
\hline Intraoperative blood loss (ml) (median, range) & $20(10-30)$ & $20(5-40)$ & 0.63 \\
\hline $\begin{array}{l}\text { Anastomosis type }(n, \%) \\
\text { Stapled } \\
\text { Hand-sewn }\end{array}$ & $\begin{array}{c}4(6.6) \\
5(66.7)\end{array}$ & $\begin{array}{l}57(93.4) \\
13(32.3)\end{array}$ & 0.01 \\
\hline Drain $(n, \%)$ & $1(3.4)$ & $28(96.6)$ & 0.09 \\
\hline Postoperative blood transfusion (n, \%) & $2(40.0)$ & $3(60.0)$ & 0.04 \\
\hline $\begin{array}{l}\text { Clavien-Dindo classification (n, \%) } \\
2 \\
\text { 3A } \\
\text { 3B }\end{array}$ & $\begin{array}{l}7 \\
0 \\
2\end{array}$ & $\begin{array}{l}4 \\
1 \\
0\end{array}$ & $<0.001$ \\
\hline
\end{tabular}

ity to eliminate gas or stool and radiologically by dilatation and air-fluid levels in the small intestine (3). POI is one of the most common complications following $\operatorname{LIC}(4,14)$. In our study, POI was found to be the most common complication following LIC. Performing hand-sewn anastomosis of LIC and using an open technique in the first surgery were found to be independent risk factors for $\mathrm{POI}$.
In laparoscopic surgery, POI is less common and its duration is shorter since laparoscopic surgery causes less inflammatory cell activation compared to open surgery $(15,16)$. However, results of numerous studies comparing adhesion formation after laparoscopic or open surgery are contradictory (17). The risk of adhesive small bowel obstruction has been found to be lower following laparoscopic colorectal surgery in a prospective co- 
Table 3. Multivariate analyzes* of risk factors for postoperative ileus

\begin{tabular}{|c|c|c|c|c|}
\hline \multirow[b]{2}{*}{ Parameters } & \multicolumn{4}{|c|}{$\begin{array}{c}\text { Multivariate analysis } \\
\text { 95\% C.I. }\end{array}$} \\
\hline & OR & Lower & Upper & p \\
\hline First operation (Laparoscopy) & 6.400 & 1.201 & 34.103 & 0.03 \\
\hline Anastomosis type (Stapled) & 6.250 & 1.1158 & 33.279 & 0.03 \\
\hline
\end{tabular}

hort study and meta-analysis $(18,19)$. However, the same finding could not be demonstrated in the randomized controlled trial (classic trial) of Guillou et al (20). In our study, compared to open surgery, $\mathrm{POI}$ was less frequent when the initial procedure was performed laparoscopically (5.6\% vs. $24.0 \%, p=0.02)$. Using an open technique in the first surgery was found to be an independent risk factor for $\mathrm{POI}(\mathrm{p}=0.03)$.

There are two techniques used in LIC: stapled anastomosis and hand-sewn anastomosis. Stapled anastomoses are performed in a side-to-side anastomosis, whereas end-to-end technique is generally used in the hand suture groups (21). Due to the fact that the distal limb is not functional for some time, anastomosis is generally made on a relatively small caliber of the distal limb, if restored in an end-to-end configuration. Therefore, perioperative edema might compromise the luminal diameter causing an early bowel obstruction (22). It has been suggested that stapled closure of a loop ileostomy may reduce $\mathrm{POI}$ since the lumen created using a stapled side-to-side anastomosis may be wider than that created by hand-sewn closure $(23,24)$. In one randomized controlled trial and three meta-analyses, it has been reported that $\mathrm{POI}$ risk is lower for stapler anastomosis ( $p=0.02, p=0.01, p<0.001, p=0.01$; respectively) $(21,22,25)$. In our study, side-to-side anastomosis was done with a stapler, and end-to-end anastomosis was done by hand. We found that stapler anastomosis was an independent risk factor for POI (OR: 6.250, $p=0.03)$.

Grass et al. have found that advanced patient age increases POI risk ( $p=0.049$ ) (1). In the study by Man et al., prolonged ileus has been observed to be more common in patients aged $\geq 80$ years $(p=0.02) 26$. Contrary to the literature, the risk of POI was higher in patients aged $<60$ years in our study $(17.6 \%$ vs. $0 \%$, $p=0.02$, respectively); however, patient age $<60$ years was not an independent risk factor for POI.

Distal colorectal resection or total colectomy/proctocolectomy is important in the development of POI. It has been reported that FAP increases POI risk $(p=0.001)$ and is an independent risk factor for $\mathrm{POI}(\mathrm{p}=0.004)$ (27). In our study, it was found that total colectomy/proctocolectomy owing to FAP increased the risk of $\mathrm{POI}(30.0 \%$ vs. 8.7\%, $\mathrm{p}=0.048)$, but was not an independent risk factor for $\mathrm{POI}$.
There are no specific guidelines or timing for assessing the most suitable LIC duration (28). Although there are studies reporting 1-12 weeks for early LIC and 2-6 months for late LIC, LIC duration is usually performed after 8-12 weeks (29-31). Early LIC is associated with more overall complications and wound complications after closure, and it may delay the completion of adjuvant chemotherapy $(28,32)$. Therefore, early LIC is not generally recommended for patients with rectal cancer (28). Conversely, having ileostomy during adjuvant chemotherapy has been shown to increase stoma output, leading to dehydration, electrolyte disturbances, and renal failure $(28,33)$. In a recent meta-analysis, it has been found that LIC during or after adjuvant chemotherapy does not change the risk of POI (34). In our study, loop ileostomy was closed in eight patients within $\leq 2$ months following the first surgery, and in 71 patients $>2$ months following the first surgery. LIC duration was 10 months or more in 13 of the 71 patients. Early LIC of these patients was delayed due to their comorbid conditions, infection or excoriation of the skin of stoma circumference. We found that LIC duration ( $\leq 2$ months vs $>2$ months) did not change the risk of $\mathrm{POI}(p=1.00)$. Since $50.6 \%$ of our patients received adjuvant chemotherapy, LIC was closed after adjuvant chemotherapy. We found that adjuvant chemotherapy did not change the risk of POI $(p=0.22)$.

Our study has some limitations: (1) All data that may affect the risk of $\mathrm{POI}$ could not be obtained owing to the retrospective nature of the study, (2) Colorectal surgery was performed for many reasons in the patients (heterogeneous sample), which can change the POI rate and risk factors (3) Small patient sample may have reduced the effectiveness of some subgroup analyses, (4) The study was performed in a single center and therefore, POC and their management may differ from other centers.

\section{CONCLUSION}

$\mathrm{POI}$ is an important complication after LIC. Using an open technique in the first surgery and performing a hand-sewn anastomosis of LIC may increase POI. 
Ethics Committee Approval: The approval for this study was obtained from Inonu University Non-Interventional Clinical Research Ethics Committee (Decision No: 2017/26-2, Date: 05.12.2017).

Peer-review: Externally peer-reviewed.

Author Contributions: Concept - A.A., C.K., M.A., A.D.; Design - A.A., C.K. M.A., A.D.; Supervision - C.K., M.A., A.D.; Data Collection and/or ProcessingA.A., C.K.; Analysis and/or Interpretation -A.A., C.K., M.A., A.D.; Literature Review - A.A., C.K., M.A., A.D.; Writing Manuscript - A.A., C.K., M.A., A.D.; Critical Reviews - A.A., C.K., M.A., A.D.

Conflict of Interest: The authors have no conflicts of interest to declare.

Financial Disclosure: No financial support was used for this study.

\section{REFERENCES}

1. Grass F, Pache B, Butti F, Solà J, Hahnloser D, Demartines N, et al. Stringent fluid management might help to prevent postoperative ileus after loop ileostomy closure. Langenbecks Arch Surg 2019; 404: 39-43. [CrossRef]

2. D'haeninck A, Wolthuis AM, Penninckx F, D'hondt M, D'hoore A. Morbidity after closure of a defunctioning loop ileostomy. Acta Chir Belg 2011; 111:136-41. [CrossRef]

3. Williams LA, Sagar PM, Finan PJ, Burke D. The outcome of loop ileostomy closure: a prospective study. Colorectal Dis 2008; 10: 460-4. [CrossRef]

4. Mengual-Ballester M, García-Marín JA, Pellicer-Franco E, GuillénParedes MP, García-García ML, Cases-Baldó MJ, et al. Protective ileostomy: complications and mortality associated with its closure. Rev Esp Enferm Dig 2012; 104: 350-4. [CrossRef]

5. Baig MK, Wexner SD. Postoperative ileus: a review. Dis Colon Rectum 2004; 47: 516-26. [CrossRef]

6. Tevis SE, Carchman EH, Foley EF, Harms BA, Heise CP, Kennedy GD. Postoperative ileus more than just prolonged length of stay? I Gastrointest Surg 2015; 19: 1684-90. [CrossRef]

7. Kaidar-Person O, Person B, Wexner SD. Complications of construction and closure of temporary loop ileostomy. J Am Coll Surg 2005; 201: 759-73. [CrossRef]

8. Slieker J, Hubner M, Addor V, Duvoisin C, Demartines N, Hahnloser D. Application of an enhanced recovery pathway for ileostomy closure: a case-control trial with surprising results Tech Coloproctol 2018; 22: 295-300. [CrossRef]

9. Bhalla A, Peacock O, Tierney GM, Tou S, Hurst NG, Speake WJ, et al. Day-case closure of ileostomy: feasible, safe and efficient. Colorectal Dis 2015; 9: 820-3. [CrossRef]

10. Keller DS, Swendseid B, Khan S, Delaney CP. Readmissions after ileostomy closure: cause to revisit a standardized enhanced recovery pathway? Am J Surg 2014; 208: 650-5. [CrossRef]

11. Grobler SP, Hosie KB, Keighley MRB. Randomised trial of loop ileostomy in restorative proctocolectomy. Br Surg 1992; 79: 903-6. [CrossRef]

12. Prevention CfDCa. Surgical site infection (SSI) event. Centers for Disease Control and Prevention website. http://www.cdc.gov/nhsn/ PDFs/pscmanual/9pscssicurrent.pdf. Published 2016. Accessed date: 24.11.2016. [CrossRef]

13. Marwah S, Singla S, Tinna P. Role of gum chewing on the duration of postoperative ileus following ileostomy closure done for typhoid ileal perforation: a prospective randomized trial. Saudi J Gastroenterol 2012: 18:111-7. [CrossRef]
14. Löffler T, Rossion I, Bruckner T, Diener MK, Koch M, von Frankenberg $M$, et al. Hand suture versus stapling for closure of loop ileostomy (HASTA Trial): results of a multicenter randomized trial. Ann Surg 2012; 256: 828-35. [CrossRef]

15. The FO, Bennink RJ, Ankum WM, Buist MR, Busch OR, Gouma DJ, et al. Intestinal handling-induced mast cell activation and inflammation in human postoperative ileus. Gut 2008; 57: 33-40. [CrossRef]

16. Schwenk W, Böhm B, Haase O, Junghans T, Müller JM. Laparoscopic versus conventional colorectal resection: a prospective randomised study of postoperative ileus and early postoperative feeding. Langenbecks Arch Surg 1998; 383: 49-55. [CrossRef]

17. Sebastian A, Stupart D, Watters DA. Loop ileostomy reversal after laparoscopic versus open rectal resection. ANZ J Surg 2019; 89: e52-5. [CrossRef]

18. Rosin D, Zmora O, Hoffman A, Khaikin M, Bar Zakai B, Munz Y, et al. Low incidence of adhesion-related bowel obstruction after laparoscopic colorectal surgery. J Laparoendosc Adv Surg Tech A 2007; 17: 604-7. [CrossRef]

19. Yamada T, Okabayashi K, Hasegawa H, Tsuruta M, Yoo JH, Seishima $R$, et al. Meta-analysis of the risk of small bowel obstruction following open or laparoscopic colorectal surgery. Br J Surg 2016; 103: 493-503. [CrossRef]

20. Guillou PJ, Quirke P, Thorpe H, Walker J, Jayne DG, Smith AM, et al. Short-term endpoints of conventional versus laparoscopic-assisted surgery in patients with colorectal cancer (MRC CLASICC trial): multicentre, randomised controlled trial. Lancet 2005; 365: 1718-26. [CrossRef]

21. Löffler T, Rossion I, Gooßen K, Saure D, Weitz J, Ulrich A, et al. Hand suture versus stapler for closure of loop ileostomy--a systematic review and meta-analysis of randomized controlled trials. Langenbecks Arch Surg 2015; 400: 193-205. [CrossRef]

22. Markides GA, Wijetunga IU, Brown SR, Anwar S. Meta-analysis of handsewn versus stapled reversal of loop ileostomy. ANZ J Surg 2015; 85: 217-24. [CrossRef]

23. Williams NS, Nasmyth DG, Jones D, Smith AH. De-functioning stomas: a prospective controlled trial comparing loop ileostomy with loop transverse colostomy. Br J Surg 1986; 73: 566-70. [CrossRef]

24. Gong J, Guo Z, Li Y, Gu L, Zhu W, Li J, et al. Stapled vs hand suture closure of loop ileostomy: a meta-analysis. Colorectal Dis 2013; 15: e561-8. [CrossRef]

25. Hasegawa H, Radley S, Morton DG, Keighley MR. Stapled versus sutured closure of loop ileostomy: a randomized controlled trial. Ann Surg 2000; 231: 202-4. [CrossRef]

26. Man VC, Choi HK, Law WL, Foo DC. Morbidities after closure of ileostomy: analysis of risk factors. Int J Colorectal Dis 2016; 31: 51-7. [CrossRef]

27. Vergara-Fernández O, Trejo-Avila M, Salgado-Nesme N. Multivariate analysis of risk factors for complications after loop ileostomy closure. Cir Cir 2019; 87: 337-46. [CrossRef]

28. Wang L, Chen X, Liao C, Wu Q, Luo H, Yi F, et al. Early versus late closure of temporary ileostomy after rectal cancer surgery: a meta-analysis. Surg Today 2020; [Epub ahead of print] [CrossRef]

29. Alves A, Panis Y, Lelong B, Dousset B, Benoist S, Vicaut E. Randomized clinical trial of early versus delayed temporary stoma closure after proctectomy. Br J Surg 2008; 95: 693-8. [CrossRef] 
30. Zhou M-W, Wang Z-H, Chen Z-Y, Xiang J-B, Gu X-D. Advantages of early preventive ileostomy closure after total mesorectal excision surgery for rectal cancer: an institutional retrospective study of 123 consecutive patients. Dig Surg 2017; 34: 305-11. [CrossRef]

31. Nelson T, Pranavi AR, Sureshkumar S, Sreenath GS, Kate V. Early versus conventional stoma closure following bowel surgery: A randomized controlled trial. Saudi J Gastroenterol 2018; 24: 52-8. [CrossRef]

32. Sandra-Petrescu F, Herrle F, Hinke A, Rossion I, Suelberg H, Post S, et al. CoCStom trial: study protocol for a randomised trial comparing completeness of adjuvant chemotherapy after early versus late diverting stoma closure in low anterior resection for rectal cancer. BMC Cancer 2015; 15: 923. [CrossRef]
33. Oliphant R, Czerniewski A, Robertson I, McNulty C, Waterston A, Macdonald $A$. The effect of adjuvant chemotherapy on stoma-related complications after surgery for colorectal cancer: a retrospective analysis. J Wound Ostomy Continence Nurs 2015; 42: 494-8. [CrossRef]

34. Hajibandeh S, Hajibandeh S, Sarma DR, East J, Zaman S, Mankotia $R$, et al. Meta-analysis of temporary loop ileostomy closure during or after adjuvant chemotherapy following rectal cancer resection: the dilemma remains. Int J Colorectal Dis 2019; 34: 1151-9. [CrossRef]

\section{ORIJINAL ÇALIŞMA-ÖZET}

Turk J Surg 2020; 36 (4): 333-339

\section{Loop ileostomi kapatılması sonrası postoperatif ileus için risk faktörleri}

Aydın Aktaş ${ }^{1}$, Cüneyt Kayaalp ${ }^{2}$, Mustafa Ateş ${ }^{3}$, Abuzer Dirican ${ }^{3}$

${ }^{1}$ Karadeniz Teknik Üniversitesi Tıp Fakültesi, Genel Cerrahi Anabilim Dalı, Trabzon, Türkiye

${ }^{2}$ Inönü Üniversitesi Tıp Fakültesi, Gastrointestinal Cerrahi Anabilim Dalı, Malatya, Türkiye

${ }^{3}$ Inönü Üniversitesi Tıp Fakültesi, Genel Cerrahi Anabilim Dalı, Malatya, Türkiye

\section{ÖZET}

Giriş ve Amaç: Loop ileostomi kapatılması (LIK) sonrası en sık görülen karın içi komplikasyon postoperatif ileus'tur (POi). Çalışmanın amacı, LiK sonrası gelişen POI için risk faktörlerini belirlemek ve onun önlenmesi için önerilerde bulunmaktır.

Gereç ve Yöntem: Bu çalışmaya distal kolorektal cerrahi sonrası peristomal insizyon ile LiK uygulanan hastalar dahil edildi. Postoperatif komplikasyonları değerlendirmek için Clavien-Dindo sınıflaması kullanıldı. POI ve postoperatif kaçak klinik ve radyolojik kriterlere göre tanımlandı. Cerrahi alan enfeksiyonu (CAE) tanısında Hastalık Kontrol ve Önleme Merkezleri-2017 kriterleri kullanılmıştır. Cerrahi sonrası birinci günde hemoglobin seviyesinde $>2 \mathrm{~g} / \mathrm{dL}$ veya $\geq \% 15$ 'ten fazla azalma olması durumunda postoperatif kanama teşhisi konuldu.

Bulgular: Yetmiş dokuz hasta çalışmaya dahil edildi. Dokuz hastada POI, altı hastada CAE, beş hastada postoperatif kanama ve iki hastada anastomoz kaçağı gelişti. Tek değişkenli analizde; yaş $<60$ yaş $(p=0,02)$, komorbidite varlığı $(p=0,007)$, ilk cerrahide açık teknik kullanılması $(p=0,02)$, ilk cerrahide total kolektomi yapılması $(p=0,048)$, LíK anastomozunun elle yapılması $(p=0,01)$ ve postoperatif kan transfüzyonu ( $p=0,04)$ POi için risk faktörleri olarak bulundu. LiK anastomozunun elle yapılması $(p=0,03)$ ve ilk cerrahide açık teknik kullanılması $(p=0,03)$ POI riski için bağımsız değişkenler olarak bulundu.

Sonuç: Ilk ameliyatta açık bir tekniğin kullanılması ve loop ileostomi kapamanın elle yapılması postoperatif ileusu artırabilir.

Anahtar Kelimeler: Leostomi kapama, ince bağırsak tıkanıklığı, kolorektal cerrahi, elle anastomoz yapma, laparoskopi

Doi: $10.47717 /$ turkjsurg.2020.4911 